Vol.14, No.1, Mei 2018, pp. 5-13

ISSN: 2613-9944 (Online) ISSN: 0216-4981 (Print)

DOI : $10.29238 / j t k . v 14 i 1.85$

\title{
COMIC EDUCATION MEDIA ON FOOD LABEL WITH FOLKLORE CHARACTER FOR CHILDREN
}

\section{MEDIA EDUKASI KOMIK TENTANG LABEL MAKANAN DENGAN TOKOH CERITA RAKYAT UNTUK ANAK}

\begin{tabular}{|c|c|}
\hline \multicolumn{2}{|c|}{$\begin{array}{c}\text { 1Jurusan Gizi, Poltekkes Kemenkes Yogyakarta } \\
{ }^{2} \text { Laboratorium Bahasa, Poltekkes Kemenkes Yogyakarta }\end{array}$} \\
\hline Article Info & ABSTRACT/ABSTRAK \\
\hline Article history: & $\begin{array}{l}\text { Lack of awareness in food label reading could be a problem of eating habit in } \\
\text { Indonesian especially in youth. School-aged children are susceptible group to }\end{array}$ \\
\hline $\begin{array}{l}\text { Received Feb } 21^{\text {st }}, 2018 \\
\text { Revised Mar } 2^{\text {nd }}, 2018 \\
\text { Accepted Ma } 16^{\text {th }}, 2018\end{array}$ & $\begin{array}{l}\text { have risk from unsafe packaged snack food. Comic book would be one of good } \\
\text { education media for them. Aim of the study was to raise awareness to food label } \\
\text { reading and to make a good media to educate youth to read packaged } \\
\text { food/snack label. This study was a research and development study ( } R \text { and D }\end{array}$ \\
\hline Keyword: & $\begin{array}{l}\text { stuay) with } 4 \text { approach (deilne, aesign, develop, alsseminate). Atter designing } \\
\text { the media (including storyline and cover design) the media was rated by } 2 \text { media }\end{array}$ \\
\hline $\begin{array}{l}\text { Comic } \\
\text { Media } \\
\text { Food Labelling } \\
\text { Feasibility }\end{array}$ & $\begin{array}{l}\text { experts, tested in school-aged children, and also requested feedback from } \\
\text { school teachers. Quantitative data were shown in percentage of feasibility, while } \\
\text { qualitative data were analyzed by saturation of data. The rating test from } \\
\text { experts showed that overall comic feasibility was } 87,86 \% \text { (means feasible to } \\
\text { use). The testing from users or school-aged children showed that overall comic } \\
\text { feasibility was } 96,41 \% \text { (means feasible). The school teachers gave positive } \\
\text { feedbacks on comic book. The conclusion of the study is that the comic book } \\
\text { about food labelling with folklore character is feasible to use. }\end{array}$ \\
\hline
\end{tabular}

\section{Kata Kunci :}

Komik

Media

Label Makanan

Kelayakan

\begin{abstract}
Kurangnya kesadaran akan pembacaan label makanan menjadi masalah kebiasaan makan di Indonesia terutama pada remaja. Anak usia sekolah adalah kelompok rentan pada makanan kemasan yang tidak aman. Buku komik dapat menjadi salah satu media edukasi mengenai label makanan kemasan untuk mereka. Tujuan dari penelitian ini adalah untuk meningkatkan kesadaran terhadap pembacaan label makanan dan membuat media yang baik untuk mendidik anak muda untuk membaca kemasan makanan/makanan ringan.Penelitian ini merupakan research and development study (studi $R$ and D) dengan pendekatan 4D (define, design, develop, disseminate). Setelah merancang media (termasuk alur cerita dan desain sampul) media dinilai oleh 2 pakar media, diuji pada anak usia sekolah, dan juga dimintakan umpan balik dari guru sekolah. Data kuantitatif ditunjukkan dalam persentase kelayakan, sedangkan data kualitatif dianalisis dengan saturasi data. Uji rating dari ahli media menunjukkan bahwa kelayakan komik secara keseluruhan adalah $87,86 \%$ (layak untuk digunakan). Pengujian dari pengguna atau anak-anak sekolah menunjukkan bahwa tingkat kelayakan komik adalah 96,41\% (berarti layak dilakukan). Guru sekolah memberikan umpan balik positif pada buku komik. Kesimpulan dari penelitian ini adalah buku komik tentang makanan labelling dengan karakter tradisional layak untuk digunakan
\end{abstract}

\section{Corresponding Author:}

Almira Sitasari,

Jurusan Gizi,

Poltekkes Kemenkes Yogyakarta,

Jl. Tatabumi No.3 Banyuraden, Gamping, Sleman, Yogyakarta

Email: almira.sita@poltekkesjogja.ac.id 


\section{PENDAHULUAN}

Menurut Data Riskesdas, konsumsi makanan beresiko di Daerah Istimewa Yogyakarta cukup tinggi. Sebanyak $69,2 \%$ penduduk mengkonsumsi makanan manis lebih dari 1 kali perhari. ${ }^{1}$ Selain itu, penduduk Yogyakarta mengkonsumsi makanan berlemak/ berkolesterol/ gorengan, makanan berpengawet, dan berpenyedap cukup tinggi yakni masing-masing50,1\%; 4\%; dan 77,8\% jika dibandingkan dengan rerata nasional. Dalam tingkat nasional, 1 dari 10 penduduk Indonesia mengkonsumsi mie instan lebih dari 1 kali sehari. Hal ini dapat menggambarkan tingginya potensi konsumsi makanan beresiko, tidak terkecuali makanan kemasan pada penduduk Indonesia khususnya di Yogyakarta.

Anak usia sekolah (AUS) adalah kelompok yang cukup sering terpapar makanan beresiko tersebut seperti makanan kemasan dan/atau jajanan. Penelitian di Bogor pada tahun 2007 menemukan bahwa jajanan memberikan kontribusi energi sebanyak rata-rata $234-311 \mathrm{kcal} / \mathrm{hari}^{2}$. Konsumen anak dan remaja memiliki hak yang sama seperti konsumen dewasa yakni berhak mendapatkan informasi atas produk yang dikonsumsi terutama makanan. Selain itu, konsumen khususnya konsumen anak juga berhak mendapatkan pendidikan dalam pembacaan dan penggunaan label tersebut ${ }^{3}$.

Menurut sumber dari Yayasan dan Lembaga Konsumen Indonesia menyebutkan bahwa 96\% penduduk di Indonesia membaca label makanan. Kendati demikian, label makanan tidak dibaca secara detil. Sebagian besar masyarakat hanya membaca tanggal kadaluwarsa sedangkan nomor registrasi yang merupakan penanda legalnya suatu produk sangat jarang dibaca dan diperhatikan ${ }^{4}$.

Penulis menilai pentingnya edukasi terhadap AUS mengenai kesadaran dan pengetahuan tentang membaca label makanan kemasan sebelum memutuskan membeli atau mengkonsumsi suatu makanan. Dari hasil wawancara, selama ini edukasi kesehatan pada anak sekolah dasar dilakukan dalam pelajaran IPA dan Pendidikan Jasmani. Selama ini media tersebut kurang memberikan unsur hiburan sehingga mudah dilupakan anak. Oleh karena sasaran edukasi adalah anak sekolah dasar, penulis mencoba mengembangkan media edukasi komik karena merupakan salah satu media kegemaran AUS. Hal ini juga diharapkan menumbuhkan awareness tentang pembacaan label makanan. Konten cerita rakyat dipilih karena AUS sudah familiar dengan cerita rakyat. Selain itu, komik dengan cerita rakyat juga dapat menumbuhkan kecintaan anak terhadap budayanya sendiri. Maka tujuan penelitian ini adalah untuk menilai kelayakan media edukasi komik dengan tohok cerita rakyat sebagai media edukasi pembacaan label makanan pada anak.

\section{METODE PENELITIAN}

Penelitian ini merupakan penelitian mixed method (kualitatif dan kuantitatif) dengan rancangan penelitian pengembangan. Model penelitian yang digunakan adalah model Four D Models (Define, Design, Develop, Disseminate).Urutan tahap penelitian adalah 1) desain tokoh; 2) alur cerita (storyline); 3)visualisasi dalam gambar; 4) desain cover; 5) penilaian ahli media; 6) uji coba terbatas kepada users; 7) indepth interview untuk mendapat feedback media kepada guru SD.

Pemilihan lokasi penelitian dilakukan dengan random sampling sementara pemilihan siswa dilakukan dengan purposive sampling. Penelitian dilakukan di SD Demak ljo 2 dengan jumlah total 57 sampel yang berasal dari kelas 4 dan 5 . Kelayakan media baik pada penilaian ahli media dan uji coba terbatas pada users dinilai "layak" jika skor rata-rata dan skor masing-masing item penilaian $\geq 61 \%{ }^{5}$. Indepth interview dilakukan kepada 4 orang responden dengan analisis saturasi data intervew. 


\section{HASIL DAN PEMBAHASAN}

Desain Komik dikembangkan setalah melakukan proses "Define" dari referensi mengenai label makanan. Tokoh utama dipilih dari hasil wawancara dengan pengampu mata pelajaran dan wali kelas dengan suara terbanyak. Dari keempat informan penelitian, seluruhnya menyatakan bahwa Gatot Kaca adalah tokoh cerita rakyat yang paling familiar dengan anak-anak SD.

Tahap pertama dilakukan desain tokoh utama "Gatot Kece" dan tokoh pendamping "Nogo". Desain pertama terlihat pada Gambar 1 berikut :
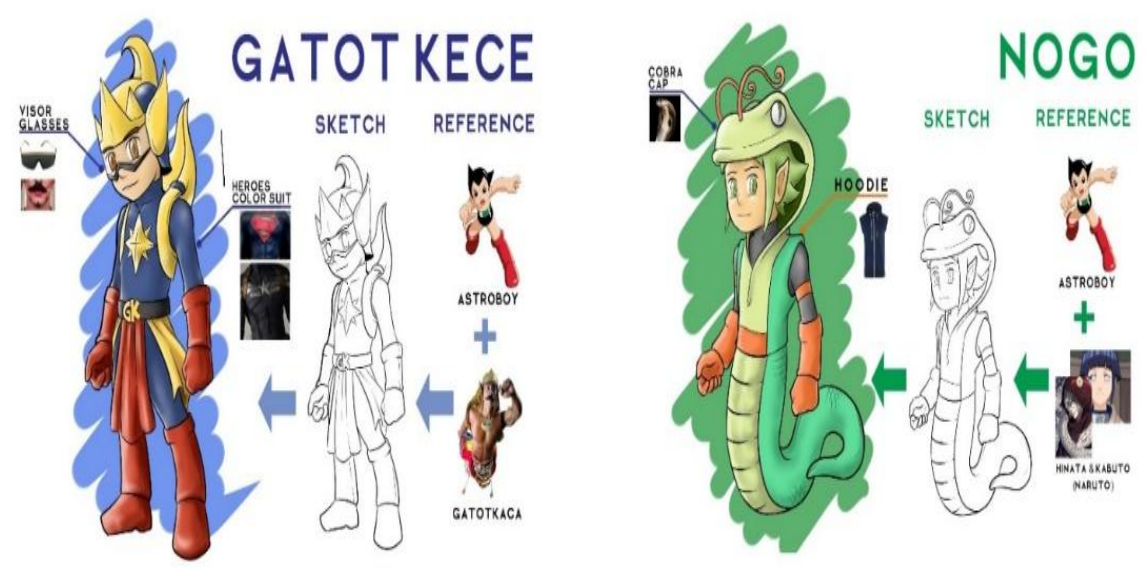

Gambar 1. Desain Tokoh Utama dan Pendamping Komik Kisah Gatot Kece dan Makanan Kemasan

\subsection{Storyline/Alur Cerita}

Tahap berikutnya merupakan desain komik dengan alur cerita (storyline). Beberapa desain konten komik tergambar pada Gambar 2 berikut :

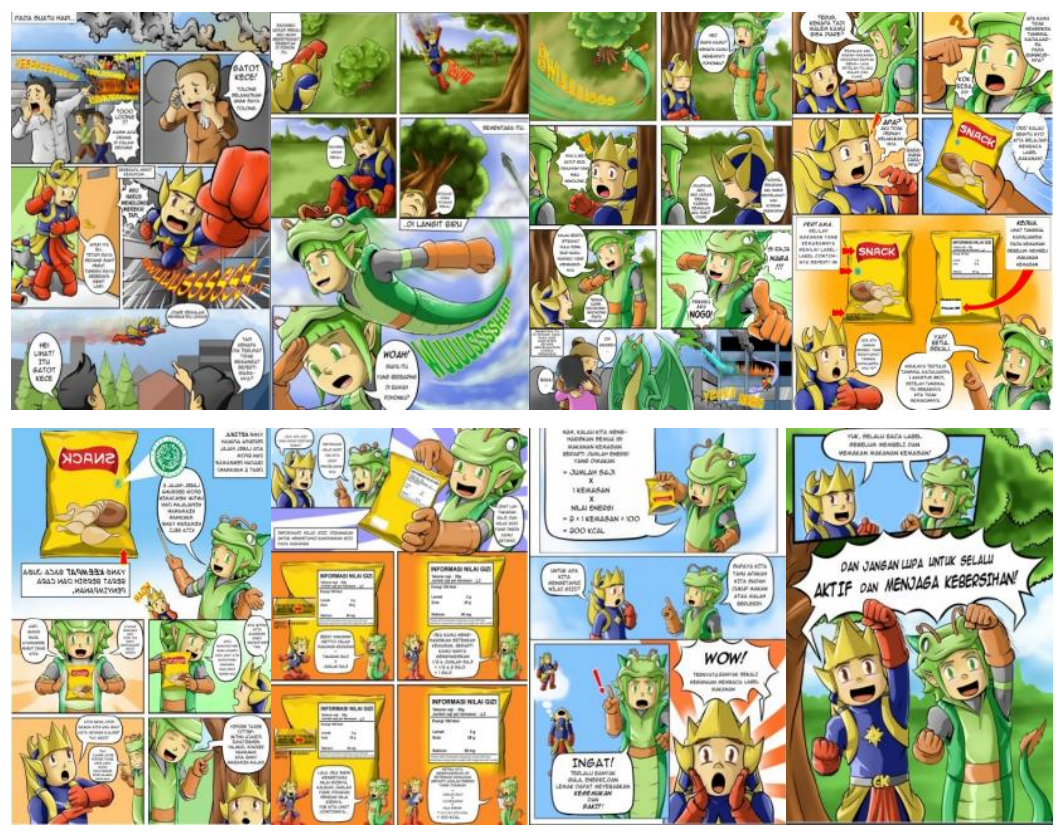

Gambar 2. Alur Cerita Komik

\subsection{Desain Cover}

Tahap ketiga dilakukan desain terhadap cover buku Komik "Kisah Gatot Kece dan Makanan Kemasan". Hasil desain cover tertera dalam gambar 3 berikut : 


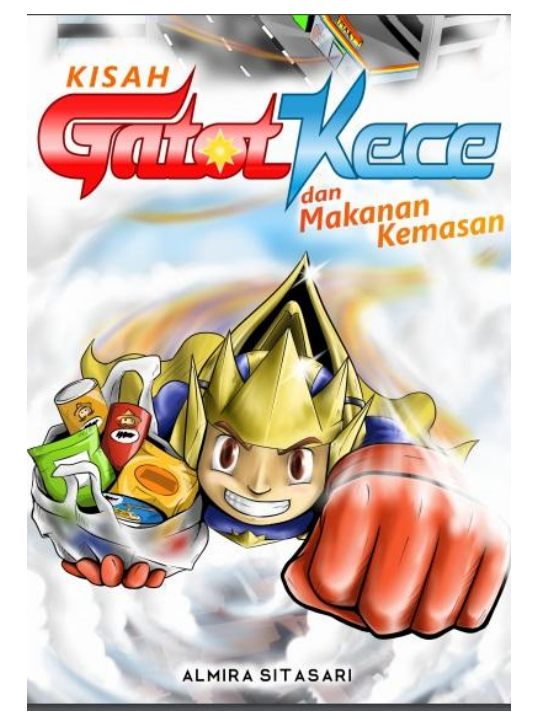

Gambar 3. Desain Sampul Komik

\subsection{Kelayakan Media (Oleh Ahli Media)}

Validasi konten dilakukan oleh dosen media di lingkungan Jurusan Gizi Poltekkes Kemenkes Yogyakarta. Hasil validasi oleh ahli media secara ringkas disajikan pada tabel 1.

Tabel 1. Hasil Validasi Media

\begin{tabular}{|c|c|c|}
\hline No & Aspek Kelayakan & $\begin{array}{l}\text { Kelayakan } \\
(\%)\end{array}$ \\
\hline \multicolumn{3}{|c|}{ Format tampilan Media Komik } \\
\hline 1. & Penampilan sampul komik & 90 \\
\hline 2. & $\begin{array}{l}\text { Keterbacaan tulisan dengan jenis dan ukuran huruf yang } \\
\text { sesuai }\end{array}$ & 90 \\
\hline 3. & $\begin{array}{l}\text { Gambar dan ilustrasi yang digunakan sesuai dengan materi } \\
\text { labelling }\end{array}$ & 80 \\
\hline 4. & Latar belakang sederhana & 90 \\
\hline 5. & Ukuran gambar & 90 \\
\hline 6. & Ukuran kertas & 90 \\
\hline 7. & Pilihan warna sesuai & 90 \\
\hline \multicolumn{3}{|c|}{ a. Rata-rata Kelayakan Format tampilan Media $=88,6$} \\
\hline \multicolumn{3}{|c|}{ Materi Komik } \\
\hline 8. & Tema cerita & 80 \\
\hline 9. & Tema cerita dan materi sesuai & 90 \\
\hline 10. & $\begin{array}{l}\text { Materi labelling tidak menimbulkan banyak tafsir sesuai } \\
\text { dengan fakta, prinsip, konsep }\end{array}$ & 80 \\
\hline 11. & Penyajian konsep mudah dicerna & 80 \\
\hline 12. & Merangsang siswa untuk membaca & 100 \\
\hline & Alur cerita penyajian & 80 \\
\hline \multicolumn{3}{|c|}{ b. Rata-rata Kelayakan Materi Komik = 85} \\
\hline \multicolumn{3}{|c|}{ Penyajian Bahasa Media Komik } \\
\hline 14. & $\begin{array}{l}\text { Bahasa sesuai dengan perkembangan peserta didik dengan } \\
\text { menggunakan Bahasa yang sederhana, singkat, dan jelas }\end{array}$ & 90 \\
\hline 15. & Menggunakan Bahasa dengan struktur kalimat yang tepat & 90 \\
\hline 16. & $\begin{array}{l}\text { Istilah dan kosakata yang digunakan tepat dengan konsep } \\
\text { labelling }\end{array}$ & 90 \\
\hline \multicolumn{3}{|c|}{ c. Rata-rata Kelayakan Bahasa Komik = 90} \\
\hline & -rata Kelayakan Media $=87,67$ & \\
\hline
\end{tabular}


Kelayakan rata-rata media komik secara keseluruhan berdasarkan penilaian validator yang meliputi aspek format tampilan media, format materi dan format bahasa komik sebesar $87,86 \%$. Hal ini menunjukkan bahwa media komik ini telah layak diterapkan karena seluruh skor memenuhi nilai $\geq 61 \%{ }^{5}$. Pengembangan suatu komik sebagai sebaiknya memenuhi beberapa syaratantara lain kata yang sederhana dan mudah dibaca, kalimat yang ditulis ringkas, jelas, padat dan mudah dimengerti, komponen media visual harus saling terkait sebagai satu kesatuan yang utuh dan menyeluruh, penekanan tertetu yang dianggap penting oleh pengguna (users) dapat diberi tanda, dan lainnya. Selain prinsip-prinsip di atas, pengembangan komik sebagai media visual juga harus memperhatikan hal bentuk, garis, tekstur dan warna.

\subsection{Uji Coba Terbatas (Oleh Users)}

Uji Coba dilakukan untuk memperoleh kelayakan empiris media yang dikembangkan dan berikut hasil uji coba terbatas tercantum pada tabel 2 .

Tabel 2. Hasil Uji Coba Terbatas

\begin{tabular}{|c|c|c|c|c|}
\hline \multirow{2}{*}{ No } & \multirow{2}{*}{ Aspek yang Dinilai } & \multicolumn{2}{|c|}{ Respon Siswa } & \multirow{2}{*}{ Skor (\%) } \\
\hline & & $\mathrm{Ya}$ & Tidak & \\
\hline \multicolumn{5}{|c|}{ Materi Komik } \\
\hline 1. & $\begin{array}{l}\text { Apakah gambar dapat membantu Adik } \\
\text { untuk mengerti tentang label makanan? }\end{array}$ & 54 & 3 & 94,73 \\
\hline 2. & $\begin{array}{l}\text { Apakah alur cerita dapat membantu Adik } \\
\text { untuk mengerti tentang label makanan? }\end{array}$ & 56 & 1 & 98,25 \\
\hline 3. & $\begin{array}{l}\text { Apakah Adik merasa mudah mengerti label } \\
\text { makanan dengan membaca komik ini? }\end{array}$ & 54 & 3 & 94,73 \\
\hline \multicolumn{5}{|c|}{ Kelayakan Rata-rata Materi Media Komik = 95,9 } \\
\hline \multicolumn{5}{|c|}{ Tampilan Komik } \\
\hline 4. & Apakah tampilan komik sudah bagus? & 55 & 2 & 96,5 \\
\hline 5. & Apakah gambar menarik? & 56 & 1 & 98,25 \\
\hline 6. & Apakah Bahasa mudah dipahami? & 57 & 0 & 100 \\
\hline 7. & Apakah ukuran dan jenis huruf terbaca? & 57 & 0 & 100 \\
\hline 8. & Apakah warna sudah menarik? & 56 & 1 & 98,25 \\
\hline \multicolumn{5}{|c|}{ Kelayakan Rata-rata Tampilan Media Komik = 98,6 } \\
\hline \multicolumn{5}{|c|}{ Ketertarikan Siswa } \\
\hline 9. & $\begin{array}{l}\text { Apakah komik ini menarik minat adik } \\
\text { mempelajari label makanan? }\end{array}$ & 55 & 2 & 96,5 \\
\hline 10. & $\begin{array}{l}\text { Apakah Adik ingin pelajaran lain diajarkan } \\
\text { dalam bentuk komik? }\end{array}$ & 53 & 4 & 92,98 \\
\hline \multicolumn{5}{|c|}{$\begin{array}{l}\text { Besar Presentase Ketertarikan Siswa Dalam Menggunakan Media Komik } \\
=94,74\end{array}$} \\
\hline
\end{tabular}

Kelayakan rata-rata respon siswa dalam uji coba terbatas dalam penggunaan media komik secara keseluruhan yang meliputi aspek format materi, format tampilan dan bahasa komik diperoleh persentase skor 96,41\%. Respon siswa ini menunjukkan bahwa komik edukasi mengenai label makanan kemasan telah valid atau layak dengan ketentuan memperoleh persentase $\geq 61$. Kelayakan rata-rata materi media komik sebesar $95,9 \%$. Pada format tampilan media komik mendapatkan persentase sebesar 94,74. Secara umum tampilan media komik menurut respon siswa sangat layak digunakan karena tampilan dalam komik sudah dirasa bagus dengan pemilihan warna yang tepat. Namun ada siswa menyatakan penyajian bahasa komik masih cenderung susah. Bahasa 
percakapan dalam balon kata yang digunakan dalam komik ini menyesuaikan dengan karakter tokoh dan disesuaikan dengan bahasa keseharian siswa. Siswa tertarik pada media komik label makanan. Berdasarkan persentase siswa memberikan respon positif sebanyak $96,5 \%$ pada aspek ketertarikan dalam menggunakan media komik pada edukasi mengenai label makanan dan 92,98\% siswa menyatakan tertarik untuk menggunakan media komik dalam pembelajaran pada tema yang lain. Persentase ketertarikan siswa, bila di interpretasikan, sangat layak untuk digunakan oleh siswa. Hal ini menunjukkan bahwa peranan pokok komik sebagai media pembelajaran adalah kemampuannya dalam menciptakan minat siswa ${ }^{6}$. Komik merupakan suatu jembatan untuk menumbuhkan minat baca, menunjukkan bahwa membaca adalah kegiatanyang amat menyenangkan. Komik bukan hanya sekedar media hiburan tetapi komik bisa menjadi media untuk mendidik dan mengajar ilmu pengetahuan dan moral kepada siswa. Buku komik menyediakan kriteria-kriteria yang sederhana, mudah ditangkap dan dipahami isinya, sehingga sangat digemari baik oleh anak-anak maupun orang dewasa ${ }^{7}$.

\subsection{Kelayakan Media (Oleh Guru)}

Untuk mengetahui feedback kelayakan media komik "Kisah Gatot Kece dan Makanan Kemasan", peneliti melakukan indepth interview kepada guru SD.

Dari 4 informan, dikatakan bahwa media komik belum menjadi salah 1 yang populer di sekolah.

\section{Kotak 1}

"Pembelajaran temanya tentang apa maksudnya tingkat pembelajaran dia mau pakai mediaapa, kalau misal pake media komik kayaknya jarang sih. Paling yang sering buku-buku perpus tapi jarang juga sih."

Titik, Guru Bahasa Inggris

Keempatnya juga menyatakan bahwa media komik untuk edukasi sebaiknya tidak digunakan saat pelajaran. Media komik bisa digunakan saat istirahat. Selain itu, media komik juga bisa digunakan saat di rumah atau pada saat pembiasaan (30 menit sebelum dimulainya pembelajaran di kelas).

\section{Kotak 2}

"Ya mendingan pas istirahat"

Titik, Guru Bahasa Inggris

\section{Kotak 3}

"Tapi kan sebagian hidupnya anak tinggal di rumah, nah anak cenderung lebih, lebih suka dengan hal-hal yang menarik dengan tv, dengan bacaan, koran, atau ya kayak gini dengan komik, poster atau apa anak punya ketertarikan"

Tatik, Wali Kelas IV

\section{Kotak 4}

"Seperti ini bisa diberi di pelajaran, ada IPA sama pembiasaan itu" 
Bagi anak, kegiatan membaca buku bergambar atau komik merupakan kegiatan menghibur dan menyenangkan dengan gambar-gambar yang atraktif, berwarna dengan format sampul yang bagus dan menarik. sehingga dilihat dari penampilannya saja anak sudah mulai tertarik untuk melihat dan segera membaca buku tersebut.

Dari keempat informan menyatakan bahwa konten dalam media komik sudah layak. Alur cerita menarik dan tidak dapat ditebak.

\section{Kotak 5}

"Isinya sangat mendidik. Gatotkaca ya seorang apa ya pahlawan yang berjuang untuk anak-anak, tapi karena dia sakit dia belum membantu mungkin anak-anak juga pernah seperti itu tapi apa ya...Emm ada kendala sakit atau apa".

Siska, wali kelas VI

Terdapat 2 informan menyatakan bahwa konten yang lebih penting adalah keamanan pangan dan perilaku hidup bersih dan sehat. Sementara 2 informan lainnya mengatakan bahwa edukasi membaca label makanan sangat diperlukan.

\section{Kotak 6}

"Kalau saya sih edukasi mengenai label makanan itu perlu sekali, karena anak kan tidak di sekolah saja. Di rumah kan mungkin deket warung, mungkin sering jajan di mall atau apa yang bisa beli kemasan-kemasan gitu harus kenal".

Tatik, wali kelas IV

\section{Kotak 7}

"...tentang makanan-makanan yang bikin diare itu, iya kayaknya itu penting juga. Label makanan juga penting agar anak tidak sembarangan membeli jajan. Mungkin juga tentang menjaga makanan apa memilih makanan yang bersih jajanan yang sehat itu penting juga untuk saat ini".

Titik, Guru Bahasa Inggris

Seluruh informan menyatakan bahwa tampilan media edukasi menarik dan menarik minat anak untuk membaca. Tampilan media komik disukai karena berwarna (full color) dan bergambar. Selain itu karakter, cerita, gambar, percakapan, dan pengemasannya menarik.

\section{Kotak 8}

"Buku yang ada gambarnya dan berwarna biasanya mereka suka, seneng sekali. Untuk yang buku bacaan tulisan itu kadang mereka wes wegah dilirik".

Titik, Guru Bahasa Inggris

\section{Kotak 9}

"..., kalau secara tampilan sudah menarik nggih, menarik disini fullcolor, kontraslah kalo dilihat ya menarik kemudian juga pemilihan tokohnya kita sudah kenal. Sudah kenal walaupun atau mungkin karena ini ya Gatotkaca jadi namanya Gatotkece ya diplesetkan, tapi kita juga sudah kenal lah, wo, ini pahlawan itu to, terus untuk tulisannya juga sudah sudah jelas kebaca nggih kan, karena untuk memahami isinya kan harus mudah terbacanggih. Ini sudah bisa terbaca jelas".

Tutun, wali kelas II 
Siswa sekolah dasar berada pada tahap perkembangan kognitif yang berbeda dengan siswa sekolah pada jenjang berikutnya. Dalam teori perkembangan intelektual yang dikembangkan Piaget, siswa sekolah dasar berada pada tahap konkrit, apabila diberikan konsep tanpa disertai contoh yang konkrit, maka siswa akan mendapatkan kesulitan dalam mempelajarinya ${ }^{8}$. Akibatnya, siswa tidak memiliki minat dan keinginan untuk mempelajari konsep tersebut. Oleh karena itu, komik yang dapat memberikan gambaran konkrit pendidikan gizi merupakan salah satu media pilihan untuk siswa. Menurut Dale dalam "Kerucut Pengalaman Dale", kemampuan diterimanya konten edukasi bergantung pada media yang dipilih. Komik merupakan media visual artinya pesan yang ingin disampaikan disajikan dalam bentuk gambar atau grafik. Konten edukasi melalui media visual dapat diserap sebanyak $30 \%$ oleh penerimanya ${ }^{9}$.

Keterserapan pesan juga didukung oleh seberapa atraktif media yang dipilih. Warna merupakan salah satu faktor keatraktifan suatu media. Warna diketahui dapat mempengaruhi emosi dan perilaku seseorang. Selain itu warna juga dapat dipakai dalam mempengaruhi seseorang, pengambilan keputusan, dan mempengaruhi kesehatan ${ }^{10}$. Dengan kata lain, warna adalah stimulasi yang halus dengan dampak yang menonjol dan sangat mempengaruhi kehidupan manusia secara fisik, fisiologis, dan sosiologis. Setiap warna memiliki panjang gelombang tersendiri. Misalnya warna merah yang memiliki panjang gelombang terpanjang sehingga diistilahkan dengan warna panas dan warna ungu yang memiliki panjang gelombang lebih pendek dibandingkan dengan warna merah, kuning, atau oranye. Setiap gelombang warna inilah yang akan membawa pengaruh berbeda terhadap fungsi fisiologis pada mata dan akan memberikan efek berbeda terhadap otak ${ }^{11}$.

Dalam pemilihan media edukasi kesehatan, hasil dalam mempengaruhi seseorang serta pengambilan keputusan seseorang merupakan faktor yang penting untuk dipertimbangkan. Salah satu media yang dapat digunakan sebagai literasi adalah komik. Komik merupakan gabungan dari unsur : sastra dan seni visual sehingga dapat membuatnya sebagai media edukasi pedagogi (pembelajaran untuk anak-anak) yang efektif ${ }^{12}$. Komik dinilai merupakan "kendaraan" yang sangat baik untuk menyampaikan pengetahuan ilmiah karena kemampuannya dalam memadukan visual grafis dan narasi sehingga menjadi sesuatu yang atraktif bagi pembacanya ${ }^{13}$.

Pemilihan cerita dan karakter dalam komik juga merupakan hal yang tidak dapat diabaikan dalam pembuatan komik untuk edukasi pedagogi. Salah satu karakter yang digemari dan strategis untuk dipakai adalah superhero. Walau superhero bukan merupakan tokoh yang nyata namun tetap menjadi pilihan karena merupakan karakter yang dapat menarik perhatian dan menghibur seseorang. Komik tidak selalu harus bersifat humor. Salah satu bentuk komik yang bersifat "serius" adalah komik edukasi. Komik tersebut dimaksudkan untuk menjelaskan/mendidik pembaca mengenai sains atau konsep ilmiah lainnya. Konten ilmiah terkadang dapat disampaikan dengan teknik fiktif dan narasi ${ }^{14}$.

\section{KESIMPULAN}

Rata-rata kelayakan media menurut ahli media adalah $87,86 \%$. Rata-rata kelayakan menurut users adalah 96,41\%. Menurut informan, media komik layak digunakan lebih lanjut pada pengguna. Secara keseluruhan, komik layak digunakan. Media komik sebagai edukasi gizi dapat digunakan selama jam istrahat atau pada saat sesi pembiasaan di kelas. Komik sejenis dapat dibuat dengan konten keamanan pangan (memilih makanan dan jajanan yang sehat) serta perilaku hidup bersih dan sehat (PHBS). 


\section{DAFTAR PUSTAKA}

[1] Badan Penelitian dan Pengembangan Kesehatan Kementerian Kesehatan RI. Riset Kesehatan Dasar 2013. Diakses pada tanggal 1 Desember 2016 dari www.depkes.go.id

[2] Lusiana SA dan Dwiriani CM. Usia Menarke, Konsumsi Pangan, dan Status Gizi Anak Perempuan Sekolah Dasar di Bogor. Jurnal Gizi dan Pangan, November 2007 2(3): $26-35$

[3] Menteri Negara Sekretaris Negara. 1990. Undang-Undang Perlindungan Konsumen. Menteri Sekretaris Negara Republik Indonesia.

[4] Suprayatmi M. 2008. Kebiasaan Makan pada Anak-Anak. Diunduh dari www.academia.edu pada tanggal 1 Januari 2017

[5] Purwanto D. Pengembangan Media Komik IPA Terpadu Tema Pencemaran Air sebagai Media Pembelajaran untuk Siswa SMP Kelas VII. Jurnal Pendidikan Sains E-Pensa Volume 1 Nomor 1 Tahun 2013, 71-76

[6] Sudjana dan Rivai. 2002. Media Pengajaran. Bandung: Sinar Baru Algensindo

[7] Santyasa IW. (2007). Landasan Konseptual Media Pembelajaran. Makalah disajikan dalam Workshop Media Pembelajaran Bagi Guru-Guru SMA Negeri Banjar Angkan, di Banjar Angkan Klungkung, 10 Januari 2007

[8] Piaget, J. 2003. Psychology of Intelligence. Taylor and Francis Group : New York

[9] Dale, E. (1969) Audiovisual methods in teaching, third edition. New York: The Dryden Press; Holt, Rinehart and Winston

[10] Jalil NAB, Yunus NAB, Said NS. 2011. Environmental Colour Impact upon Human Behaviour: A Review. Social and Behavioral Sciences 35 (2012) : $54-62$

[11] Fehrman, K. R., \& Fehrman, C. 2004. Color: The Secret Influence (2nd ed.). Upper Saddle River, NJ: Pretice Hall

[12] Rota, G., \& Izquierdo, J.. Comics as a tool for teaching biotechnology in primary schools. Electronic Journal of Biotechnology(2003), 6(2), 86-88

[13] Weitkamp, E., \& Burnet, F.. The "chemedian" brings laughter to the chemistry classroom. International Journal of Science Education, (2007). 29(15), 1911-1929

[14] Tatalovic, M. Science comics as tools for science education and communication: A brief exploratory study. Journal of Science Communication(2009), 8(04), 2-4 